\title{
FLOOD RISK VULNERABILITY VISUALIZATION FOR SUSTAINABLE RISK MANAGEMENT - THE CASE OF SERBIA
}

UDC 005.334(497.11)

\author{
Jovica Stanković1, Zoran Tomić , Milan Gocić ${ }^{3}$ \\ ${ }^{1}$ University of Niš, Faculty of Economics, Niš, Serbia \\ ${ }^{2}$ University of Niš, Faculty of Agriculture, Kruševac, Serbia \\ ${ }^{3}$ University of Niš, Faculty of Civil Engineering and Architecture, Niš, Serbia \\ ORCID iD: Jovica Stanković (ㄷ) https://orcid.org/0000-0002-9174-0260 \\ Zoran Tomić (1) N.A. \\ Milan Gocić
}

\begin{abstract}
The main objective of this study is to visualize the flood risk vulnerability of municipalities in the Republic of Serbia through mapping and spatial analysis of precipitation data and data related to the losses. GIS tools enable spatial analysis and visualization of historical data on losses combined with temporal and geo-spatial distribution of precipitation, and QGIS tool was used for visualization of precipitation data and data on damages caused by floods and flash floods. As a result of these analyses, areas with potential high risks of losses are detected, which enables undertaking appropriate steps and measures in order to minimize future losses.
\end{abstract}

Key words: risk visualization, floods, GIS, spatial analysis

JEL Classification: C63, C82, C88, Q54, Q01

\section{INTRODUCTION}

Climate change is becoming the primary environmental challenge in the 21 st century. Society and economy are exposed to numerous risks which can significantly affect their development. Realization of these risks can cause material and non-material damage. It is important, both from the individual point of view and from the national point of view, to work on the identification, monitoring and prevention of the same risks. Thus, extreme

Received August 17, 2021 / Accepted December 15, 2021

Corresponding author: Jovica Stanković

University of Niš, Faculty of Economics, Trg kralja Aleksandra 11, 18000 Niš, Serbia

| E-mail: jovica.stankovic@eknfak.ni.ac.rs 
risks, natural disasters and climate change are important issues that occupy the attention of the scientific public, but also of policy makers due to the negative socio-economic consequences they may have.

The region of South East Europe is very vulnerable to climate change. Heavy rainfall and subsequent flooding in May 2014 can be considered an extremely important factor affecting the regional growth, because the floods that hit this region indicated a high degree of vulnerability and unpreparedness of countries in this region to manage such risks. Considering the fact that $17.1 \%$ of the territory and $17.5 \%$ of the population of the Republic of Serbia are at risk of natural disasters, it can be concluded that Serbia is a country of "relatively high risk of multiple hazards" (Dilley et al., 2005). Moreover, according to the projections of climate change, it can be presumed that present hazards, especially hydrological ones, may intensify (Vuković et al., 2018). This alarming estimation provided incentive for the development of improved approaches and policies for flood risk management across Europe.

Selecting an optimal risk management strategy and minimizing the negative effects of floods depends on the accuracy of precipitation assessment. Precipitation, as one of the most important parts of the Earth's water cycle, has very important role for environment and life processes, but also can have destructive role causing losses and damages. The focus of this paper is on mapping and spatial analysis of measured precipitation values using GIS tools and techniques.

The main objective of this study is to visualize the flood risk vulnerability for sustainable risk management in the Republic of Serbia through mapping and spatial analysis of precipitation data and data related to the losses. Thus, the aim of this study is twofold. The first goal is to obtain the precipitation map for the whole territory of the Republic of Serbia and to visually present registered losses. Subsequently, we intend to investigate which areas have higher risk potential caused by heavy rains and flash floods. The paper is structured as follows: section 2 provides an overview of the types and consequences of natural disasters, especially floods, and possibilities for spatial analysis of these disasters using GIS tools; data and methodology are described in section 3 and obtained results are presented in section 4 , and section 5 concludes the presented work.

\section{LITERATURE REVIEW}

A thorough knowledge on natural disasters and their short- and long-term effects on the economic system is critical precondition for conceptualization of effective mechanisms and procedures of disaster risk management. The level of economic development (Raschky, 2008), as well as employment, education and age structure of inhabitants (Noy, 2009) are some of the main determinants of national and regional society's vulnerability to natural disaster losses. Considering the effects of natural processes on the human community, as well as the effects of human activities on shaping the environment, it can be concluded that there is a strong bi-directional and multidimensional relation between natural and social processes (Kovačević-Majkić et al., 2014). The changes in climate parameters already affect GDP, as well as revenues within sectors which are particularly important to the growth and development of the Serbian economy - agriculture and production, transmission and distribution of electric power and heat energy (World Bank, 2015). Moreover, given the expected climate changes, the impact on the GDP of the Republic of Serbia is expected to 
continue. It is also apparent that the negative influence of climate change on the GDP is increasing with the rise in mean global temperatures (Božanić and Mitrović, 2019, p. 6). Although exposed to multiple types of natural hazards, flooding is a recurring risk that largely varies depending on exposure, vulnerability and coping capacity (Stanković, Tomić \& Stanković, 2020). The floods, that are caused by prolonged intervals of rainfall and intensive snow melting, "are occurring most frequently in the Vojvodina region and along with the river courses of the Sava, Drina, Velika Morava, Južna Morava and Zapadna Morava". Flash floods caused by short intensive rainfall can occur in the smaller river basins (Stat, 2018, pp. 2).

Thus, economic development should be complemented by investments in adapting to climate change and mitigating the effects in order to transform the society in the ongoing transition process. The approach to flood risk management has changed and became more comprehensive and sustainable in order to achieve the financial resilience and minimize the negative effects of natural disasters on the economic growth of the Republic of Serbia (World Bank Group, 2016). This change has been promoted by international actions and legislation, while at the European level the most important act is the European Floods Directive 2007/60/EC, which envisages the development of Flood Risk Management Plans. The development of the Risk Management Plan in areas with significant flood risk is preceded by a preliminary flood risk assessment, preparation of flood hazard maps and flood risk maps.

There are a number of methods for visualizing data which provide different possibilities for analysing data and relations hidden in data. Selecting the appropriate visualization method is influenced by the nature of data and the intention of visualization.

Most important analyses enable comparing categorical values (i.e. comparisons between the relative and absolute sizes of categorical values), assessing hierarchies and part-of-a-whole relationships (i.e. breakdown of categorical values in their relationship to a set of values or as constituent elements of hierarchical structures), showing changes over time (i.e. exploit temporal data and show the changing trends and patterns of values over a continuous timeframe), mapping geo-spatial data (i.e. plot and present datasets with geo-spatial properties) and charting and graphing relationships (i.e. assess the associations, distributions, and patterns that exists between multivariate datasets) (Kirk, 2012).

Geographic Information System (GIS) is a special type of information system which enables collecting, storing, analyses and visualization of spatial data. It is convenient for complex research, design and management problems dealing with geo spatial data. With spatial tools and methods, which are part of modern GIS software, users can discover hidden geographic patterns in their data and detect possible spatial relations between studied phenomena. One of the main advantages of GIS systems is that it is an invaluable tool for different visualization and representation of data (Bednarz et al., 2006). Another more important feature is that GIS tools provide spatial analysis.

Spatial analysis is the process of analysing and processing spatial data in order to get valuable insights from data. Important part of the spatial analysis is data visualization. GIS tools enable generation of numerous visualizations of geo spatial-data, and the most convenient are choropleth maps, dot plot maps, bubble plot maps, contour maps, various cartograms and network connection maps. Choropleth maps are a particularly effective way for visualisation of geo-spatial data. Choropleth maps colour the corresponding geographical areas (such as municipalities or countries) in different colours, or the appropriate colour shades (from light to dark), based on quantitative values of the 
observed variables. This can show a change in value according to location, which makes it easier to spot patterns or deviations in values.

\section{DATA AND METHODOLOGY}

The Republic of Sebia was selected as the study area, and two data sources were used for analyses. The first source are monthly precipitation data from 26 meteorological stations at the selected territory. The data were obtained from the annual hydrological journals issued by the Republic Hydrometeorological Service of Serbia. The spatial distribution of selected meteorological stations was presented in Fig. 1. Precipitation data for Serbia have been analysed in different contexts started from the trend analysis (Bajat et al., 2013; Gocic and Trajkovic, 2013; Unkasevic and Tosic, 2011) to analysis in the context of droughts and floods (Gocic and Trajkovic, 2014).

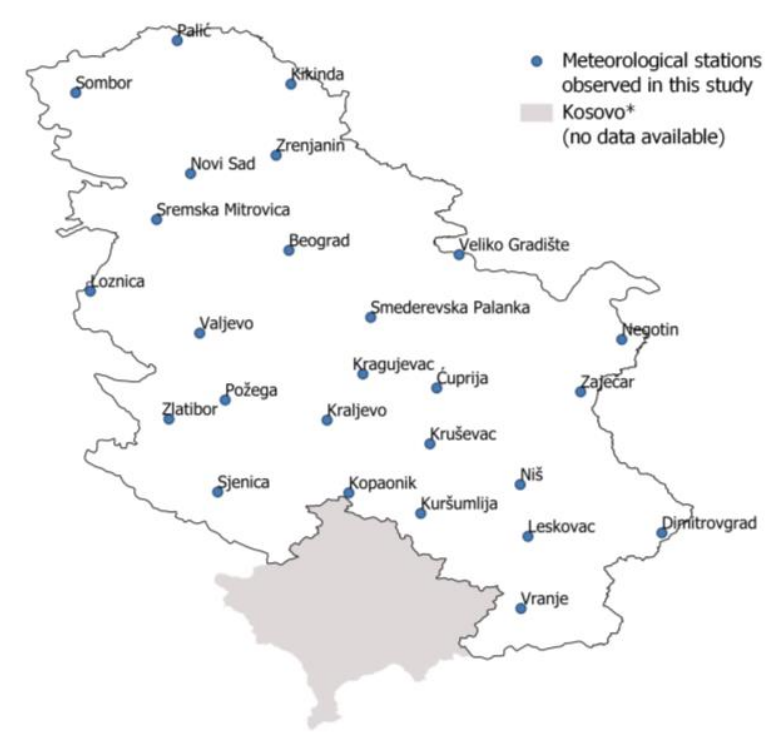

Fig. 1 Distribution of meteorological stations in Serbia

Source: Author's illustration based on data obtained from Republic Hydrometeorological Service of Serbia

Data for the analysis of disasters are obtained from the "DesInventar" database which provides disaster loss data for Sustainable Development Goals and which is developed under supervision of United Nations Office for Disaster Risk reduction (UNISDR). DesInventar offers "tools for the generation of National Disaster Inventories and the construction of databases of damage, losses and in general the effects of disasters". It contains spatial and temporal data, types of events and causes, sources of damages and both direct and indirect effects (deaths, houses, infrastructure, economic sectors etc.). The second tool is Analysis module which allows data queries for obtaining desired data and presenting that data with tables, graphics and thematic maps. It is an open-source software, 
free of charge, with aim to provide disaster loss data for Sustainable Development Goals. This database provides very detailed information on the effects of all types of disasters such as Drought, Earthquake, Explosion, Fire, Forest Fire, Flash Flood, Flood, Frost, Hailstorm, Landslide, Rains, Snowstorm, Storm, Windstorm etc. Every data entry represents single event and describes it in detail by 140 attributes such as disaster type, location of the event, time and effects of disasters (e.g., people directly and indirectly affected, number of houses destroyed or damaged etc.) The data on disaster events for the Republic of Serbia are available for the 40-year period since 1980 till 2021, and database contains a total of 2,175 data entries. The most dominant events are Forest fire (26.71\%), Flood (25.79\%), Fire (13.38\%), Hailstorm (13.38\%) and Snowstorm (6.80\%). Quality of data is not so good for earlier entries, but it has improved during time and is very detailed with numerous attributes describing each event. Publicly available dataset enables us to perform different types of analysis, including multidimensional analysis using online analytical processing (OLAP), Power pivot, geospatial analysis, and numerous data mining algorithms. The aim of these analyses is grouping data by disaster type (e.g., Flood and Flash flood), spatial dimension (e.g., Municipality or Region) and time dimension (e.g., Year), and visualization and different kind of analysis of this data from a desired perspective. According to the analysis of the temporal distribution of damages caused by floods, flash floods and landslides in the period between 2010 and 2020 (Table 1.), period between June and August 2018 was chosen for further analysis as a period with biggest number of damages caused by intensive rains in some regions of the country.

Table 1 Temporal distribution of damages caused by floods, flash floods and landslides (2010-2020)

\begin{tabular}{|c|c|c|c|c|c|c|c|c|c|c|c|c|}
\hline Month & 2010 & 2011 & 2012 & 2013 & 2014 & 2015 & 2016 & 2017 & 2018 & 2019 & 2020 & Total \\
\hline Jan & 19 & 1 & 1 & 4 & 1 & 8 & & & & & & 34 \\
\hline Feb & 7 & 3 & 7 & 5 & & 1 & & 4 & & & & 27 \\
\hline Mar & 2 & 2 & 5 & 12 & 1 & 16 & 13 & & 20 & 4 & & 75 \\
\hline Apr & 17 & 1 & 1 & 2 & 37 & 3 & 1 & & 6 & 7 & & 75 \\
\hline May & 3 & 3 & 14 & 3 & 39 & 3 & & & & 2 & & 67 \\
\hline June & 9 & & 11 & & 1 & 2 & 3 & 3 & 19 & 19 & 41 & 108 \\
\hline July & 3 & 2 & 4 & & 5 & 1 & 2 & & 15 & 1 & 1 & 34 \\
\hline Aug & 1 & 1 & 1 & & 4 & 1 & 1 & & 6 & & 2 & 17 \\
\hline Sept & 2 & 1 & & & 7 & & & & & & & 10 \\
\hline Oct & 1 & 1 & & & & & & & & & & 2 \\
\hline Nov & 4 & 1 & & & & & 2 & 1 & & & & 8 \\
\hline Dec & 11 & 1 & & & & & & & & & & 12 \\
\hline Total & 79 & 17 & 44 & 26 & 95 & 35 & 22 & 8 & 66 & 33 & 44 & 474 \\
\hline
\end{tabular}

Considering the fact that natural risks mainly influence the subsistence of people who live in rural areas and/or small municipalities, analyses of the socio-economic impacts of natural disasters will be performed in the terms of the regional development of the Republic of Serbia. The general data on the development of the regions in Serbia are presented in Table A1 in Annex.

GIS software, as mentioned before, is a commercial or open-source software for dealing with geo spatial data. For the analysis and visualization of data Quantum GIS (QGIS), OpenSource tool free of charge was used, which is very similar to ArcMap and other commercial 
GIS tools, offering powerful features for mapping and visualizing data. It offers users friendly interface and support for various datatypes, one of the most useful being shapefiles for presenting geographic areas. QGIS package release 3.16, which can be obtained from qgis.org/en/site was used for data mapping.

Shapefile with a map of the Earth for Serbia was imported as a basic layer with country borders. Second layer was created for presenting geographical position of 26 meteorological stations, and precipitation data from these stations were interpolated to present geospatial distribution of the amount of precipitation for the chosen period (period June-August 2018). Since there are only 26 available meteorological stations in the Republic of Serbia, which are not evenly spread across region, obtained information is limited to the meteorological stations, that means discrete points in space. Interpolation techniques are required for mapping corresponding meteorological variables for the whole Republic of Serbia. Precipitation map for whole country was made using spatial interpolation process in which points with known values are used for estimating values at unknown points in space. Spatial interpolation can estimate the precipitation values at locations without available data by using precipitation data at nearby meteorological stations. A suitable interpolation method has to be used for estimating the values at those locations where no samples or measurements were taken. Numerous spatial interpolation methods have already been developed for supporting transformation from point data to continuous surface map. Those methods can be divided into geographical statistics, non-geographical statistics and hybrid approach. Inverse Distance Weighting (IDW) interpolation method was chosen, as widely used for interpolation in spatial analysis and available in most GIS tools (Li et al., 2018). In the IDW interpolation method, the sample points are weighted during interpolation in such a way that closer point have higher impact and the influence of points declines with increasing distance from the point whose value is interpolated. As a result of interpolation process, a precipitation map was created for the whole region of Serbia.

Since available data about disasters are based on geographical regions (municipalities) it could be plotted as a layer on the map. Shapefile with a map of the Earth for Serbia was imported as a layer with municipality borders. Second layer was created for presenting numerical data describing disasters, and after joining map shapefile and data, that data was used to determine the colours of the map for each municipality - greater values are presented with darker colour according to defined scale.

\section{RESULTS AND DISCUSSION}

Geospatial distribution of precipitation for the period June-August 2018 in Serbia is presented in Fig. 2. According to the previously published analysis of precipitation data for the period 1946-2019 (Gocić et al., 2021), the west part of the country is the wettest part while the northern and southern parts of the country are dry. According to Fig. 2, some irregularities in precipitation distribution can be observed. Mountains Zlatibor, Kopaonik and Crni Vrh had significant values of the precipitation (more than $300 \mathrm{~mm}$ ), and municipalities with the greatest values of the total precipitation in the analysed period are Požega, Kraljevo and Sjenica with 330.7, 321.3 and $268.5 \mathrm{~mm}$, respectively. The lowest amount of precipitation was in south-east part of the country in municipalities Vranje, Negotin and Niš $(97.7 \mathrm{~mm})$. 


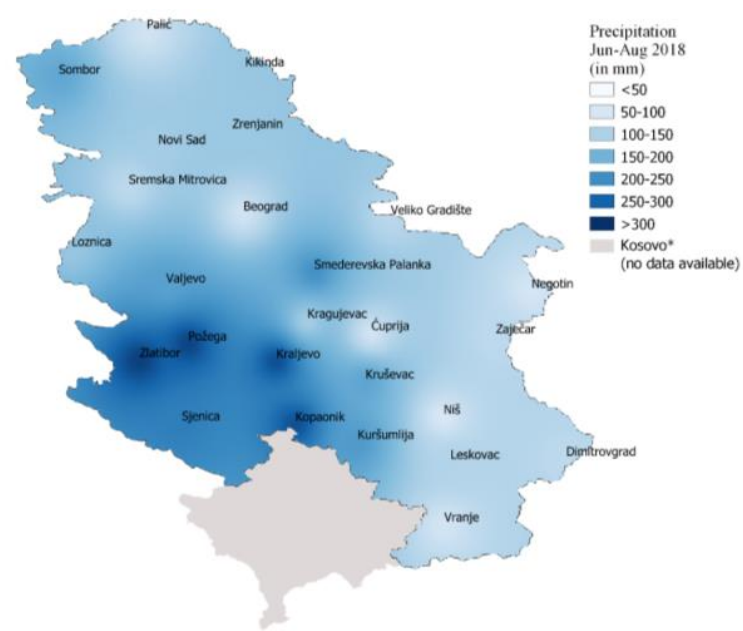

Fig. 2 Geospatial distribution of precipitation for the period June-August 2018 Source: Author's illustration

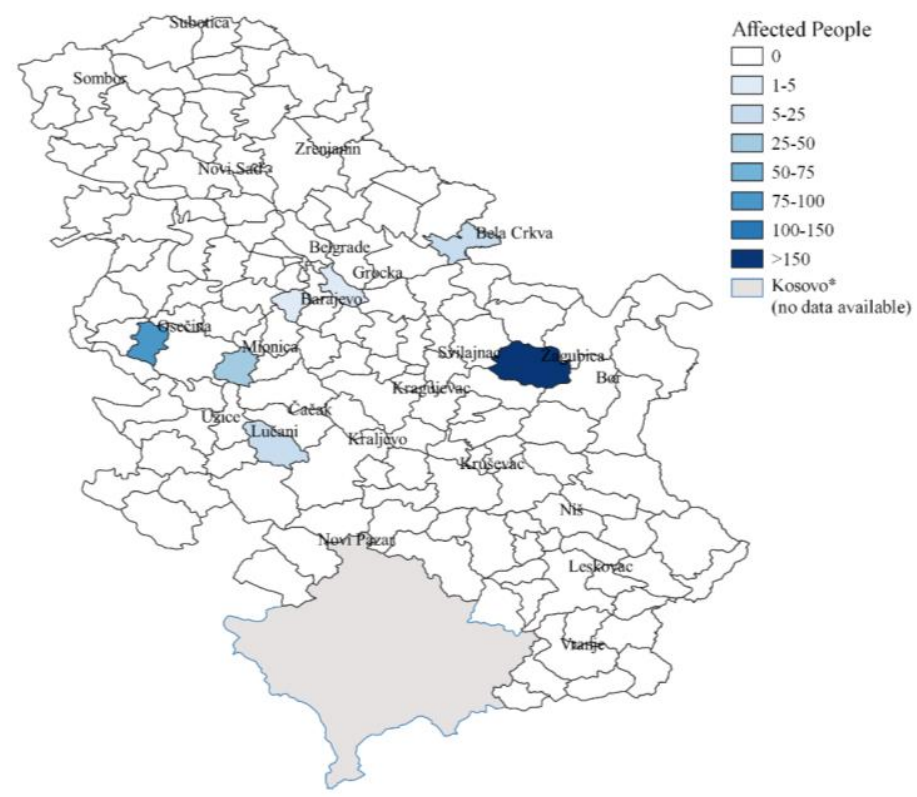

Fig. 3 Geospatial distribution of people affected by floods and landslides Source: Author's illustration

Five municipalities in Serbia (Žagubica, Osečina, Mionica, Lučani and Bela Crkva) were identified as the most vulnerable concerning the number of affected people by floods and landslides as a result of increased precipitation in the analysed period (Fig. 3). More than 20 people were affected in each of those municipalities, and the largest number of affected people was in Žagubica i.e., 419. Four out of five vulnerable municipalities territorially belong to the 
regions of Šumadija and Western Serbia and Southern and Eastern Serbia, which are characterized by large number of small municipalities. In the case of these regions, close to 2,000 municipalities are located in the area of approximately $26,000 \mathrm{~km}^{2}$. Having in mind this fact, it can be observed that every-day life and work of people in small and underdeveloped municipalities are highly affected by the flood risk.

Geospatial distribution of destroyed and damaged houses in Serbia is presented in Fig. 4. The number of destroyed and damaged houses greater than 500 houses was recorded on the territory of two municipalities (Petrovac na Mlavi and Kraljevo). Aranđelovac and Žagubica had the number of damaged houses between 250 and 500, while Čačak had 182 damaged houses. In relation to the material damage, it can be noticed that the number of destroyed and damaged houses is especially great in the municipalities located in the Region of Sumadija and Western Serbia. Considering the level of GDP per capita in this region, it is evident that people in the least developed regions suffered the most severe damage of their properties.

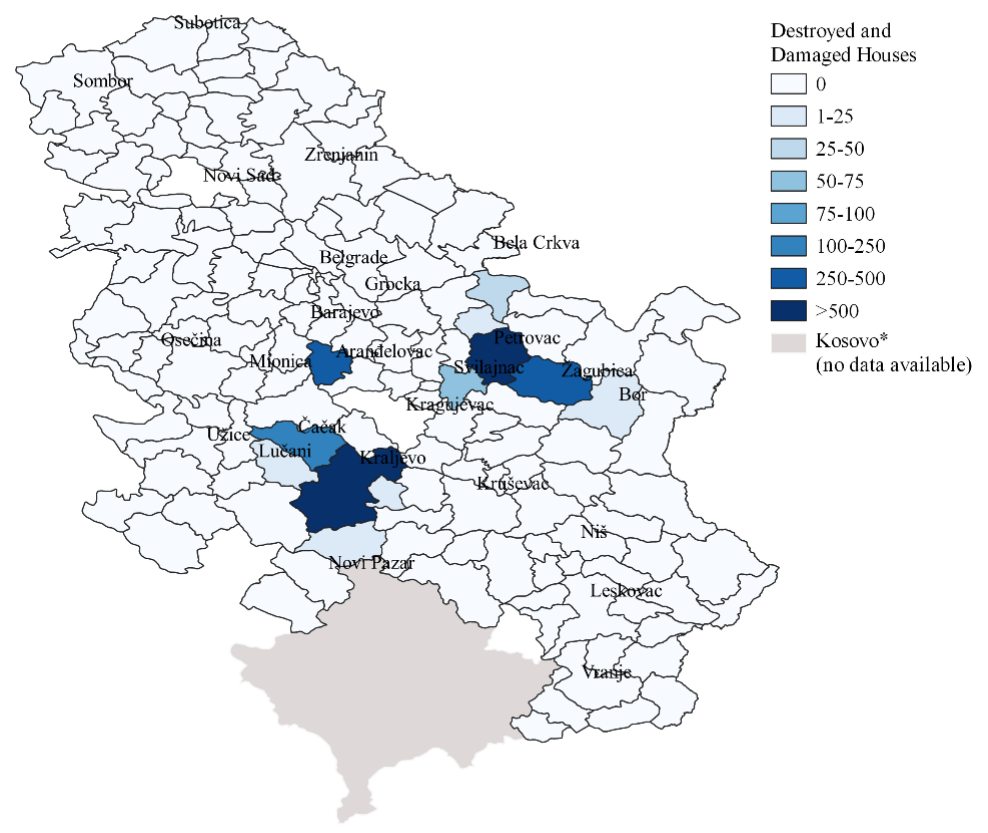

Fig. 4 Geospatial distribution of destroyed and damaged houses Source: Author's illustration

If we take into consideration the share of agriculture, forestry and fishing in GDP creation, the regions of Vojvodina (14.9\%) and Sumadija and Western Serbia (11.4\%) are especially dependent on the efficiency of this industry. Therefore, damage to crops may be examined as the indicator of the impact of natural disasters on the economy of the Republic of Serbia. Geospatial distribution of damages on crops is presented in Fig. 5. In total, thirteen municipalities were identified as a vulnerable. The damages were presented in hectares. The most significant damages on crops, on more than 1000 Hectares, were recorded in three municipalities (Velika Plana, Petrovac na Mlavi and Priboj). Important 
observation is that there were serious damages on crops in the municipalities Velika Plana and Priboj which are not followed by other damages, while in Petrovac na Mlavi there were numerous destroyed houses also. Although the manifestation of flood risk can be prevented, the concerning fact is that its influence on agriculture in the areas, where this industry is of special importance for economic development, is not mitigated.

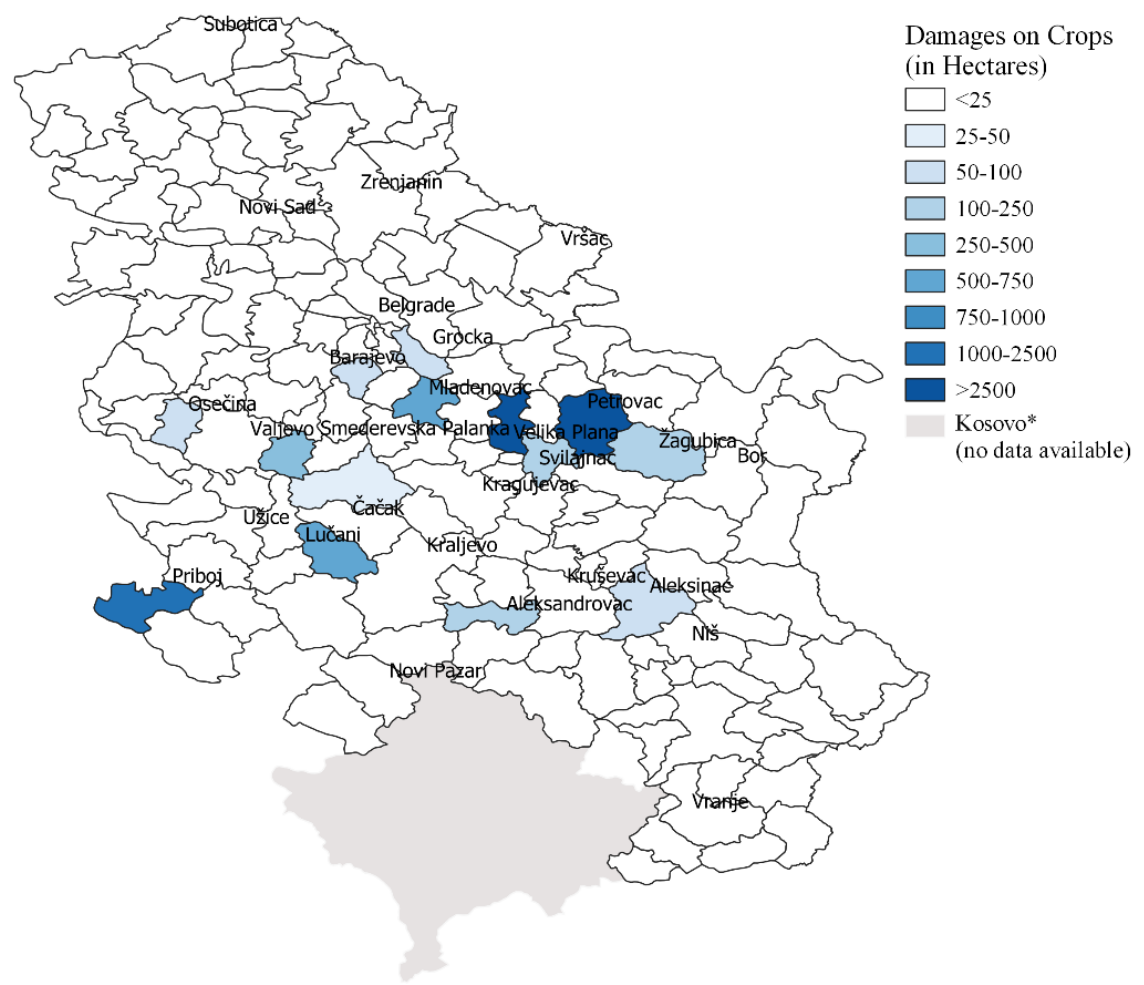

Fig. 5 Geospatial distribution of damages on crops Source: Author's illustration

Considering economic losses, the observed database records of the losses caused by natural disasters at the territory of the Republic of Serbia are presented in the local currency and only for $30.17 \%$ cases. The largest number of economic losses is available for the Region of Šumadija and Western Serbia (47.35\%) and the Region of Southern and Eastern Serbia $(30.57 \%)$, while the largest number of records concerns flood damage (46.92\%). Geospatial distribution of losses in million RSD is presented in Fig. 6. The most endangered municipality was Žagubica, while at the second level of vulnerable municipalities were Petrovac na Mlavi, Grocka and Lučani.

Detailed data on losses showed that Žagubica had the biggest losses in the observed period in all categories - 419 affected people, 304 destroyed and damaged houses, 200 Hectares of damages on crops. Unfortunately, since there is no meteorological station in Žagubica, interpolated precipitation visualization for that part of the country is not precise. Detail analysis of losses in the period between 2010 and 2020 on the territory of 
municipality of Žagubica shows that there were losses also in 2014 and 2020, the most significant are damages on crops - 320 Hectares in 2014 and 300 Hectares in 2020.

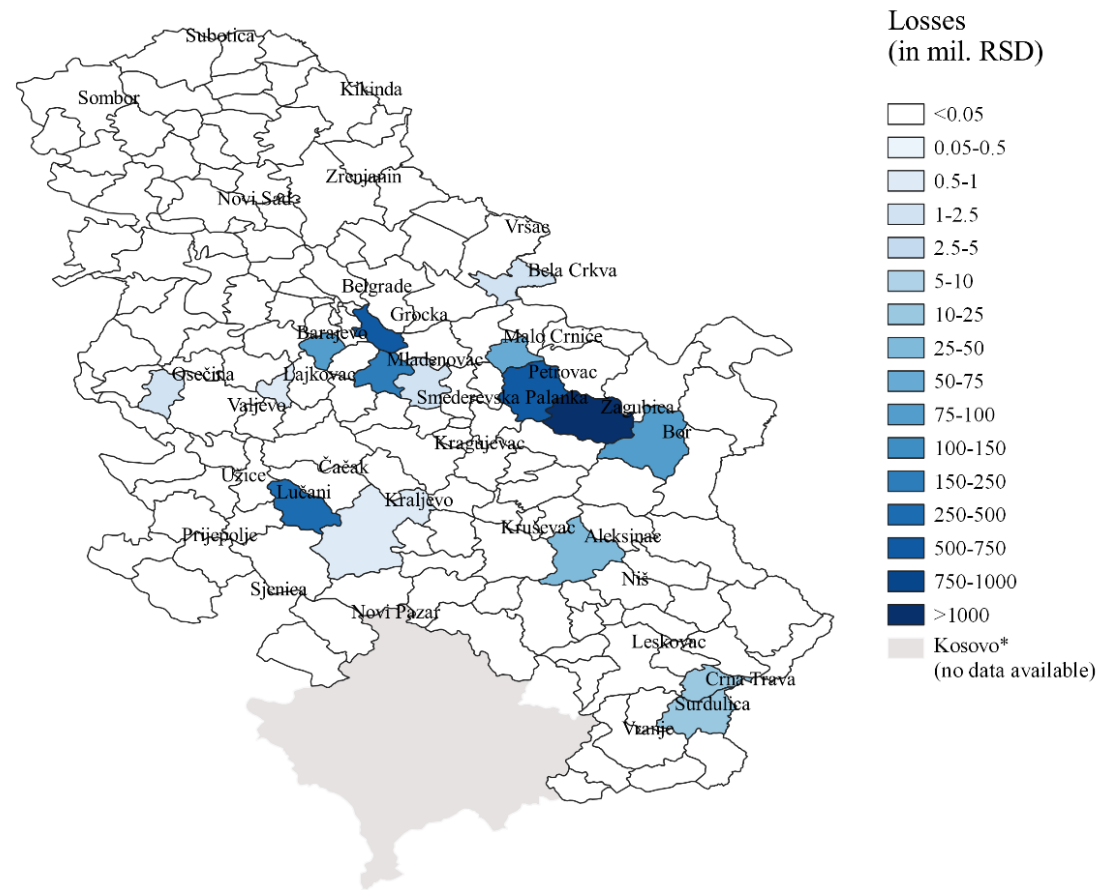

Fig. 6 Geospatial distribution of losses in million RSD Source: Author's illustration

\section{CONCLUSION}

Flash floods have a serious impact on society and economy. These events commonly occur on the limited areas and spread up to a few hundreds of square kilometres (Gaume et al., 2009). However, flash floods are the most dominant and severe hydrological risk in a number of countries. The floods are among the most frequent risk in the Republic of Serbia, i.e. $25.79 \%$ of all losses are caused by floods. The spatial distribution of damages related to floods in the Republic of Serbia, despite the different geographical characteristics of the observed regions, indicates that this risk causes greater damage to the property and crops to people in less developed regions. Thus, the municipalities in the regions of Šmadija and Western Serbia and Southern and Eastern Serbia, which are most exposed to hydrological risks, are suffering the greatest socio-economic effects of floods. The fact that flood risk is the common seasonal risk in these areas indicates the need for thorough analysis of the effects and dynamics of these risks. Comprehensive information on flood risks could enable prevention of large-scale disasters and efficient disaster risk management. Despite expectations, the average consequences of floods are increasing. Large material and economic losses affect the existence of people in these areas. This situation reveals the scarcity of firm empirical evidence on the socio-economic consequences of natural 
disasters leading to the inadequate flood risk assessment and consequently exiguous strategy for disaster risk management. Aiming to minimize the negative effects of floods, local communities face numerous challenges to transform information about precipitation into tangible implications on vulnerability and implement obtained results into concrete measures. Thus, the importance of precipitation mapping is growing considering that visual information is better communicated to different experts, as well as communities and policymakers, whose involvement in sustainable flood risk management is necessary.

GIS tools enable spatial analysis and visualization of historical data on losses (caused by flash floods, floods and landslide as a result of heavy rains) combined with temporal and geo-spatial distribution of precipitation. As a result of these analyses, areas with potential high risks of losses could be detected, and appropriate steps and measures could be undertaken in order to minimize future losses. Spatial analysis and comparison of precipitation maps and maps of losses show that there are some areas with significant losses, while other areas are not affected with similar amount of precipitation. This indicates the need to analyse landscape, geology and spatial, as well as social and economic determinants of flood risk vulnerability. Since there are only 26 available meteorological stations in the Republic of Serbia, which are not evenly spread across region, available information is limited to the location of meteorological stations and, therefore, to discrete points in space. Precipitation data for other regions is obtained by interpolation techniques, which inputs bias in analyses. Using radar and satellite data on precipitation, instead of data from rain gauges, and/or using more sophisticated interpolation algorithms, could improve analyses and provide better detection of areas with potential risk of flooding, particularly for flash floods in small catchments driven by extreme rainfall intensities over short durations.

Acknowledgement: The presented research is a part of the project of two Erasmus+ Jean Monnet Modules i.e. "Sustainable Finance and Insurance: EU Principles, Practices and Challenges" (Ref. no. 611831-EPP-1-2019-1-RS-EPPJMO-MODULE) and "EU water policy and innovative solutions in water resources management" (Ref. no. 620003-EPP-1-2020-1-RS-EPPJMO-MODULE).

\section{REFERENCES}

Bajat, B., Pejovic, M., Lukovic, J., Manojlovic, P., Ducic, V., \& Mustafic, S. (2013). Mapping average annual precipitation in Serbia (1961-1990) by using regression kriging. Theoretical and Applied Climatology 112, 1-13. https://doi.org/10.1007/s00704-012-0702-2

Bednarz, S. W., Acheson, G., \& Bednarz, R. S. (2006). Maps and map learning in social studies. Social Education, 70(7), 398. Retrieved from https://www.learntechlib.org/p/77446/

Božanić, D., Mitrović, Đ. (2019). Study on the Socio-economic Aspects of Climate Change in the Republic of Serbia. United Nations Development Program, Belgrade.

Dilley, M., Chen, R. S., Deichmann, U., Lerner-Lam, A., Arnold, M., Agwe, J., ... \& Yetman, G. (2005). Natural disaster hotspots. A global risk analysis. The World Bank. Hazard Management Unit, Washington, DC.

Gocic, M. \& Trajkovic, S. (2013). Analysis of precipitation and drought data in Serbia over the period 19802010. Journal of Hydrology 494, 32-42. https://doi.org/10.1016/j.jhydrol.2013.04.044

Gocic, M. \& Trajkovic, S. (2014). Spatiotemporal characteristics of drought in Serbia. Journal of Hydrology, 510,110-123. https://doi.org/10.1016/j.jhydrol.2013.12.030

Gocic, M., Velimirovic, L., Stankovic, M., \& Trajkovic, S. (2021). Determining the best fitting distribution of annual precipitation data in Serbia using L-moments method. Earth Science Informatics, 14(2), 633-644. https://doi.org/10.1007/s12145-020-00543-9

Kirk, A. (2012). Data Visualization: a successful design process. Packt publishing LTD.

Kovačević-Majkić, J., Panić, M., Miljanović, D., \& Miletić, R. (2014). Vulnerability to natural disasters in Serbia: spatial and temporal comparison. Natural hazards, 72(2), 945-968. https://doi.org/10.1007/s11069014-1045-3 
Li, Z., Wang, K., Ma, H., \& Wu, Y. (2018, November). An adjusted inverse distance weighted spatial interpolation method. In Proceedings of the 2018 3rd International Conference on Communications, Information Management and Network Security (CIMNS 2018). https://dx.doi.org/10.2991/cimns-18.2018.29

Longley, P. A., Goodchild, M. F., Maguire, D. J., \& Rhind, D. W. (2005). Geographic information systems and science. John Wiley \& Sons.

Noy, I. (2009). The macroeconomic consequences of disasters. Journal of Development economics, 88(2), 221231. https://doi.org/10.1016/j.jdeveco.2008.02.005

Raschky, P. A. (2008). Institutions and the losses from natural disasters. Natural hazards and earth system sciences, 8(4), 627-634. https://doi.org/10.5194/nhess-8-627-2008

Stanković, J., Tomić, Z., \& Stanković, J. (2020). Socio-economic Impact of Natural Disasters in the Republic of Serbia. Economic Analysis, 53(2), 20-38. https://doi.org/10.28934/ea.20.53.2.pp20-38

Stat, F. (2018). Food and Agricultural Organization of the United Nation. Economic and Social Department. Statistic Division (ESS). Retreived from FAO STAT website: http://www.fao.org/about/whowe-are/departments/statisticsdivision/en

Unkašević, M., \& Tošić, I. (2011). A statistical analysis of the daily precipitation over Serbia: trends and indices. Theoretical and applied climatology, 106(1), 69-78. https://doi.org/10.1007/s00704-011-0418-8

Vuković, A. J., Vujadinović, M. P., Rendulić, S. M., Đurđević, V. S., Ruml, M. M., Babić, V. P., \& Popović, D. P. (2018). Global warming impact on climate change in Serbia for the period 1961-2100. Thermal Science, 22(6 Part A), 2267-2280. https://doi.org/10.2298/TSCI180411168V

World Bank Group. (2016). Disaster Risk Finance Country Note: Serbia. World Bank.

World Bank. (2015). Coping with Floods, Strengthening Growth. South East Europe Regular Economic Report 7.

\section{VIZUELIZACIJA RANJIVOSTI OD RIZIKA POPLAVE U SVRHU ODRŽIVOG UPRAVLJANJA RIZIKOM - PRIMER REPUBLIKE SRBIJE}

Osnovni cilj ove studije je vizuelizacija ranjivosti opština u Republici Srbiji od poplava kroz mapiranje $i$ prostornu analizu podataka o padavinama $i$ gubicima. GIS alati omogućavaju prostornu analizu $i$ vizuelizaciju istorijskih podataka o gubicima u kombinaciji sa vremenskom $i$ geoprostornom distribucijom padavina, a QGIS alat je korišćen za vizuelizaciju podataka o padavinama i podataka o štetama nastalim od poplava i bujičnih poplava. Kao rezultat ovih analiza detektovana su područja sa potencijalno visokim rizicima od gubitaka, što omogućava preduzimanje odgovarajućih koraka i mera u cilju minimiziranja budućih gubitaka.

Ključne reči: vizuelizacija rizika, poplave, GIS, prostorna analiza

\section{APPENDIX}

Table A1 Regions in the Republic of Serbia - general data for 2018

\begin{tabular}{|c|c|c|c|c|c|}
\hline Regions & $\begin{array}{c}\text { Number of } \\
\text { municipalities }\end{array}$ & $\begin{array}{l}\text { Area } \\
\left(\mathrm{km}^{2}\right)\end{array}$ & $\begin{array}{l}\text { Number of } \\
\text { inhabitants* }\end{array}$ & $\begin{array}{c}\text { GDP } \\
\text { per capita } \\
\text { (000 RSD) }\end{array}$ & $\begin{array}{c}\text { GVA agriculture, } \\
\text { forestry and } \\
\text { fisheries }\end{array}$ \\
\hline Belgrade region & 174 & 3,234 & $1,690,193$ & 1,240 & $1.1 \%$ \\
\hline Vojvodina region & 446 & 21,614 & $1,861,863$ & 705 & $14.9 \%$ \\
\hline $\begin{array}{l}\text { Region of Šmadija } \\
\text { and Western Serbia }\end{array}$ & 1,935 & 26,493 & $1,924,816$ & 489 & $11.4 \%$ \\
\hline $\begin{array}{l}\text { Region of Southern } \\
\text { and Eastern Serbia }\end{array}$ & 1,967 & 26,248 & $1,505,732$ & 476 & $8.5 \%$ \\
\hline
\end{tabular}

and Eastern Serbia

Estimation made on June 30, 2018

Source: Authors' calculation, based on the data from the Statistical Office of the Republic of Serbia 